\title{
Man and the course of the spaceship Earth
}

\section{Ignacy Sachs}

EHESS/Maison de Sciences de l'Homme, 190 avenue de France, 75013 Paris, France

Email: isachs@msh-paris.fr

\begin{abstract}
Through their increasing impact, people have been weighing decisively on the course of the spaceship Earth. The entry into a new geological era, the anthropocene, marks an unprecedented disruption in the long history of the co-evolution between our species and the biosphere. Our immediate task is to draw long-term development strategies, environmentally sound and socially inclusionary, at the opposite of strategies based on the free interplay of market forces. Thus, we must give, within each nation and between nations, the utmost priority to an aggiornamento of long-term democratic planning as the main instrument of governance. The success of the second Earth Summit, due to take place in 2012 in Rio de Janeiro, will largely depend on the participants' ability to take inspiration from these principles.
\end{abstract}

Keywords: anthropocene era; mankind and the biosphere; development planning; energy sources and uses; Rio Earth Summit.

Reference to this paper should be made as follows: Sachs, I. (2012) 'Man and the course of the spaceship Earth', Atoms for Peace: An International Journal, Vol. 3, No. 3, pp.177-182.

Biographical notes: Ignacy Sachs is a Honorary Professor of the School of Advanced Social Studies (Paris). He was the founder of the CIRED (International Research Centre on Environment and Development) and was involved in the preparation of the Stockholm Conference and the first Rio Earth Summit. He was an important contributor to the concept of ecodevelopment.

\section{The anthropocene era}

The learned International Commission on Stratigraphy will meet in 2012 to tell us that we have entered into a new geological era since the beginning of the industrial revolution. We thus have been acting like Molière's Mr. Jourdain, who spoke prose without knowing it. The second Earth Summit, which will be held the same year, and for the second time in Rio de Janeiro, will help us to take due note ex post of that fact.

The anthropocene is different from the previous eras because of the part played by our species and its influence on the course of the spaceship Earth. The human emissions of ever larger amounts of greenhouse gases will soon be the cause of deleterious climate changes which could jeopardise the very future of our species, if no steps are taken to reduce these emissions. The entry into the anthropocene should be seen as an unprecedented disruption in the long history of the co-evolution between our species and 
the biosphere. According to Paul J. Crutzen and Eugene F. Stoermer (2000), a new geological era - the anthropocene - started with the industrial revolution. This term has been chosen to emphasise the astounding expansion of mankind, both in numbers and per capita exploitation of earth resources: the tenfold increase of human passengers of the spaceship Earth during the past three centuries to 6 billion, accompanied by a growth in cattle population to 1.4 billion, a tenfold growth of urbanisation in the past century and the near exhaustion of fossil fuels that were generated over several hundred million years (Lorius and Carpentier, 2010). In addition, we may mention that between 1800 and 2010, the output of the world economy was multiplied by almost 50, yet, about one billion people still suffer from food insecurity (Alves, 2011).

We might remind that the first disruption occurred some 12,000 years ago and has been known as the Neolithic revolution, marked by the domestication of various vegetal and animal species, the sedentarisation of human settlements and the very beginnings of urbanisation. ${ }^{1}$ The second, recognised ex post as the starting point of the anthropocene, was triggered by the fantastic changes brought about by the industrial revolution in terms of demographic growth, scientific and technical progress for good and evil, two world wars and major upheavals in the geopolitical setting, from the colonial age to the emancipation of the Third World, to which we should add the rise and fall of the Soviet Union.

Humanity is thus at a crossroads. Will we continue to behave like sorcerer's apprentices moved by greed and locked in 'short-termism' (as rightly stressed by Deepak Nayyar)? Or shall we mobilise ourselves to learn quickly the new function of 'geonauts', in Erik Orsenna's words, co-pilots of the spaceship Earth, capable of mitigating the deleterious climate change provoked by excessive greenhouse gas emissions, without losing from sight the social imperative - the urgent need to reduce the abyssal disparities between the affluent minority and those, much more numerous, who continue to go to bed hungry in spite of the progress achieved by the world economy?

A caveat should be introduced here. The adaptive capacity is not equally distributed among the human passengers of the spaceship Earth. One can assume that the Dutch could, were it necessary, strengthen their dykes to protect themselves from the raising sea levels. However, the same cannot be said of the inhabitants of the Maldives Islands and of Bangladesh, unless the latter count on the solidarity of richer nations, by no means granted in the present international set-up.

Up to now, there are no reasons to listen to Cassandras who pretend that our planet Gaia - will destroy us unless we learn to preserve it and reduce the world population to half a billion, equipped with nuclear energy surprisingly deemed as the safest (Lovelock, 2008). Nor should we indulge in unrestricted epistemological optimism as illustrated in a recent book edited by Brunel and Pitte (2010). The anthropocene era requires an urgent dialogue between scientists and citizens in order to overcome the narrow technoscience, which has no legitimacy to define on its own its research programmes (Testard et al., 2010).

It is a matter of urgency, but we need not yield into catastrophism. Our path is narrow and the Bible's metaphor of the needle eye comes to mind. Still, the die is not yet cast. The anthropocene is a challenge to our species that we should be able to tackle, provided that we work, to quote Louis-Joseph Lebret, towards the unfolding of a civilisation of being in the equitable sharing of having. Is it possible to say more with so few words, knowing that we are far from an equitable distribution? Yet, as shown in the path breaking study conducted by the Bariloche Foundation in Argentina (Herrera and Simon, 1977) as a response to the Club of Rome's Limits to growth (Meadows et al., 1972), eliminating appalling social disparities and lifting everybody above the threshold of a 
decent material life is a precondition to move towards this higher stage of our history, in which an ever greater parcel of societal time will be spent on cultural activities in the broadest meaning of this term: Huizinga's (1955) homo ludens will take the upper hand on the homo faber.

Income inequalities between countries and within countries are still a major hurdle to a socially inclusive and environmentally sound development at a global level. Here, we have to manage a heavy past due to the neoliberal counter-reform which followed the fall of the Berlin Wall and implosion of the Soviet Union.

\section{Planning development}

Without delay, we must go back to the concept of planned development, the opposite of the myth of the self-regulating free markets. The wind is changing once again, as the economic crisis shows a-plenty that markets are unable to regulate themselves.

Born as an offspring of war economy, central planning was adopted as the main tool of governance by the Soviet Union, at a moment when the only instrument available to planners in this huge country was the abacus. Paradoxically, planning lost its appeal at the very moment in which it could count with new powerful tools, brought about by the computer revolution. Part of the blame nowadays attached to planning comes from the misdoings of the authoritarian regimes, which used planning as a cover for arbitrary actions. However, the ultimate explanation is to be sought in the implosion of the Soviet Union and the neoliberal counter-reform fostered by the so-called Washington Consensus. It would be a pity not to make good use of the computer revolution as the conditions are at hand to begin and plan within a democratic dialogue between the developmental State, the enterprises, the workers, and the organised civil society. Our immediate task is to propose long-term development strategies, environmentally sound and socially inclusionary, ${ }^{2}$ poles opposed to the course resulting from the unconstrained play of market forces. Left to themselves, markets are short-sighted and socially insensitive, as the present crisis has once more shown. At the same time, we should reject, at least for the next few decades, the proposition to stop altogether material growth and even start a process of 'degrowth', as suggested by Serge Latouche (2006).

Let us stop playing the sorcerer's apprentices obsessed by one's short-term benefits and let us stop saying "When I'm gone, come what will". Time has come for us to behave as 'geonauts', a neologism I am borrowing from Erik Orsenna (2006) (see also the collective work presented by Erik Orsenna and Michel Petit, 2011, and Club des Argonautes at: http://www.clubdesargonautes.org/index.php). More than ever, we must obey the Imperative of Responsibility developed by Hans Jonas (1990), avoid or at least reduce environmental damages we could be generating, while doing our best to keep on with the Ascent of Man, ${ }^{3}$ which implies reducing inequalities as fast as possible. Ecological imperatives should not be a pretext to leave aside social ones. More than ever, we must stick to and attune social and environmental goals. It follows that we must give utmost priority to an aggiornamento of long-term democratic planning as the main instrument of governance within each nation and at a global level.

The UNEP (2011) has just released the first comprehensive study on green economy, rightly aimed at reconciling the twin development goals of environmental caution and social justice. The best way of advancing in this direction would consist in deciding at 
the 2012 Rio de Janeiro second Earth Summit that all UN member countries produce, say in a two-year time span, comprehensive national development plans, facing the double challenge of climate change and the urgent need to overcome poverty and social inequality.

\section{Which energy sources?}

We are not demiurges and we cannot claim to control all climate changes, but, pace Descartes, we will never be 'masters of nature' all alone. Pascal's metaphor of Man as a thinking reed is much more relevant here, as we must prepare ourselves to cunningly adapt ourselves to Nature. In order to do so, we must proactively limit our reliance on fossil energy - coal, oil and natural gas - through the sequestration and/or reuse of carbon and we must also substitute fossil energies with renewable energies.

Fortunately, yes fortunately, easily accessible oil fields are running out. Still, to do without the difficult-to-reach oil fields is out of question in the short term. For example the offshore oil field which has recently been discovered in Brazil could be explored on the condition that a large share of the incomes thus generated finances an orderly post-oil transition.

Coal reserves are much larger. Therefore, research in carbon-sequestration processes during coal combustion must be given top priority. Moreover, carbon could be reused through artificial photosynthesis. The Desertec project, designed for countries south of the Mediterranean Sea, looks at ways to use the carbon of associated gas found in oilrigs and sea-water desalinated with solar energy to develop in greenhouses a highly productive agriculture and horticulture. This project must be carried on with a sustained effort to substitute the whole range of alternative energy sources for fossil fuels: solar and wind power, tidal power plants, geothermal energy, hydroelectric stations and of course bioenergy.

As far as bioenergy is concerned, we must avoid a potential conflict between food and biofuel production, because of the farmable land scarcity. That is why the production of biofuels must rely as much as possible on the residual waste of food production, as is the case with second-generation ethanol, a.k.a cellulosic ethanol, unlike the first generation ethanol made of sugarcane. Moreover, we must ensure that the growth of biofuels production does not lead to a mass deforestation of primary forests. A recent FAO (Bogdanski et al., 2011) study rightly points to integrated Food-Energy Systems which would make good use of biomass cultivated on land and in the sea, to produce food for us and our animals, fertilisers and industry inputs. ${ }^{4}$

The blue revolution can greatly contribute to the green revolution. We are just beginning to develop the hydrosphere - seashores, rivers, natural as well as artificial lakes - and to move from fishing, in fact hunting for fish, to fish and seaweed farming, algae being a very promising source of energy.

At the same time, the substitution of fossil energy with nuclear energy raises three serious questions:

- How can we prevent research on civil nuclear energy from leading to the production of nuclear weapons which could fall into the hands of irresponsible people?

- How to transport and where to store radioactive waste so as to avoid serious accidents and their deadly consequences? 
- How to ensure a clear, transparent and effective international control which would go beyond the divide between the select club of nuclear powers and the many countries that cannot use civil nuclear energy or build nuclear weapons?

It should not surprise, under such circumstances, that a large part of public opinion is asking for a moratorium on nuclear research and on the development of nuclear energy.

One must hope that the 2012 Earth Summit will realise the challenges and opportunities facing the international community, so that the course of the spaceship Earth will enter the anthropocene in a way that allows its geonauts to build civilisations of being.

\section{References}

Alves, J.E.D. (2011) 'Economia verde, limpa e inclusiva: novo paradigma de sustentabilidade', Mercado Ético/Ecodebate, 10 February. Available online at: http://mercadoetico.terra.com.br/ arquivo/economia-verde-limpa-e-inclusiva-novo-paradigma-de-sustentabilidade/ (accessed on 22 February 2011).

Bogdanski, A., Dubois, O., Jamieson, C. and Krell, R. (2011) Making Integrated Food-Energy Systems Work for People and Climate - An Overview, FAO, Rome.

Bronowski, J. (1973) The Ascent of Man, Little Brown \& Co, London.

Brunel, S. and Pitte, J-R. (Eds) (2010) Le ciel ne va pas nous tomber sur la tête, JC Lattès, Paris.

Childe, G. (1942) What happened in History, Penguin Books, London.

Crutzen, P.J. and Stoermer, E.F. (2000) 'The "Anthropocene", Global Change Newsletter, The International Geosphere-Biosphere Programme (IGBP): A Study of Global Change of the International Council for Science (ICSU), No. 41, May 2000.

Herrera, A. and Simon, D. (1977) Un monde pour tous; le modèle mondial Latino-Américain, Presses Universitaires de France, Paris.

Huizinga, J. (1955) Homo Ludens, A Study of the Play Element in Culture, Beacon Press, Boston.

Jonas, H. (1990) Le principe responsabilité, Éditions du Cerf [original edition: 1979]; reprint by Flammarion, Paris, 1999.

Latouche, S. (2006) Le pari de la décroissance, Fayard, Paris.

Lorius, C. and Carpentier, L. (2010) Voyage dans l'anthropocène-Cette nouvelle ère dont nous sommes les héros, Actes Sud, Arles.

Lovelock, J. (2008) La revanche de Gaïa - préserver la planète avant qu'elle ne nous détruise, Éditions J'ai Lu, Paris.

Meadows, D., Randers, J. Meadows, D. (1972) The Limits to Growth, Universe Books, New York.

Orsenna, E. (2006) Portrait du Gulf Stream: Éloge des courants, Le Seuil, Paris.

Orsenna, E. and Petit, M. (2011) Climat - une planète et des hommes, Éditions du Cherche Midi, Paris.

Sachs, I. and Silk, D. (1990) Food and Energy: Strategies for Sustainable Development, United Nations University Press, Tokyo.

Testard, J., Sinaï, A. and Bourgain, C. (Eds) (2010) Labo planète ou comment 2030 se prépare sans les citoyens, Éditions Mille et une nuits, Paris.

UNEP (2011) Towards a Green Economy - Pathways to Sustainable Development and Poverty Eradication, Nairobi. 


\section{Notes}

1 See the pioneering book by Gordon Childe, What happened in History (Childe, 1942).

2 The adjective inclusionary (rather than inclusive) has been used by A.K. Sen.

3 Title of an important book by Jakob Bronowski: The Ascent of Man (Bronowski, 1973).

4 It was the main challenge of the project I conducted at the United Nations University (see Sachs and Silk, 1990). 